\title{
History and its Poetic Images in the Poetry of Luljeta Lleshanaku and Yehuda Amichai
}

\author{
Dr. Bavjola Shatro (Gami)
}

\author{
Aleksandër Moisiu University \\ Email: shatro.uamd.edu@gmail.com
}

\section{Doi:10.5901/mjss.2014.v5n20p2440}

\begin{abstract}
This article focuses on contemporary Albanian poetry and on its development during the last decade of the twentieth century when the communist regime in Albania collapsed. The article aims to give a path for further analysis on the poetry written after the 1990s which is a period that offered different and very important perspectives for Albanian literature. The development of Albanian poetry during this time and during the first decades of the $21^{\text {st }}$ century, as well as its representation abroad through translation, is closely linked to the name of one of the main spokespersons of contemporary Albanian poetry Luljeta Lleshanaku. The article focuses on the poetic images and perceptions of history in Lleshanaku's poetry and analyzes the specific poetic images and literary configurations deriving from it. The paper also designates a possible path of comparative approach with the poetry of an eminent Israeli writer of the second half of the twentieth century such as Yehuda Amichai, which is probably one of the most important influences in Lleshanaku's poetics. The vision about the world and particularly the vision on history as well as the artistic sensitivity that are a constant underscoring of the poetic images of Lleshanaku's and Amichai's poetry seem to approach two poets that belong to different cultural, political and social contexts.
\end{abstract}

Keywords: History, poetry, memory, contemporary poetry, world literature.

\section{Introduction}

Albanian literature has successfully become part of world literature especially during the twentieth century when several writers - Ismail Kadare is the most famous of them- were translated into many languages and won several important literary prizes. This fact is particularly important if we consider the political situation in Albania during the second half of the twentieth century. For almost 5 decades Albania was under the communist regime which is generally considered one of the most extreme of all the regimes in Eastern Europe. Therefore, communication with world literature and the academe abroad was hindered by unsurpassable political factors. Albanian literature went through an extreme form of censorship and an alienating process. State ideology considered literature a main tool to serve the building of socialism and used it to inculcate the materialist world view to the people. Poetry is the literary genre that suffered most the indoctrination starting from the first years of the establishment of the regime. This imposition of ideology and politics on literature caused the dwindling of all the literary product of that time and interrupted the literary process whose acme was during the 1930s and mid 1940s.

This very poor performance of Albanian literature continued until the end of the 1950s and the beginning of the 1960s when the Generation of the 1960s finally appeared and gave start to a process of revival and significant development in Albanian poetry. The poets of this Generation are Fatos Arapi, Ismail Kadare and Dritëro Agolli. Their first poetry volumes appeared mostly during the end of the 1950s and the early 1960s. They were the key figures of Albanian poetry for the whole decade and are usually considered the main representatives of contemporary Albanian poetry. These poets were inspiration and predecessors of other generations of poets which became part of the literary scene during the 1970s and 1980s. The 1970s and 1980s is a prosperous period in Albanian poetry because the previous generation continued to write and another generation of poets emerged. The poets of the 1970s and 1980s seemed to lead Albanian poetry to a poetic model, which had more urban and lyrical topics and was characterized by more sophisticated stylistic techniques. Xhevahir Spahiu, Natasha Lako, Eqrem Basha, Moikom Zeqo, Bardhyl Londo, Preç Zogaj etc. are among the representative poets of this time in Albanian literature. These poets are often considered as the third generation of poets after WWII (Elsie 2001). Their poetry contributed to a wider understanding of modernity. Modernity was now in the second stage of development and it was not perceived as a set of literary techniques that avoided punctuation or tended to replicate other similar exhibitionist formal techniques. These literary procedures weren't even allowed in communist Albania even if they contributed to a higher literary quality. Despite the ideological limitations poets aimed at a poetry which creates a wide and sophisticated concept about the world and therefore poetry written 
during this time was often characterized by a complex structure and content (Vinca 2007).

Of course modernity was a complicated issue in communist Albania especially considering the extreme censorship and the purges in arts and literature which happened in several campaigns such as those in the periods 1945-1948, 1966-1967 and 1973-1975 (Elsie 2001). Therefore topics on the socialist life, on the glorious leadership of the Party and on the development of Marxism-Leninism and its implementation in everyday life were inevitable for most of the poets but still modern poetic images were present and guaranteed the survival and the development of Albanian poetry at that time.

It was in the 1990s that a generation of nonconformist poets also known as the avant-garde of the 1990s appeared and presented a complete different view on literature and also offered a drastic separation from the previous literature written under realist socialism. This generation of poets represents a new type of poet in Albanian literature. They have their own and openly expressed literary, philosophical and critical creeds. They did not hesitate to attack and do parody of the previous literary production. The poets of the 1990s intended to test Albanian language to its limits of expression. They experimented widely with modernist and avant-garde techniques in poetry that were common especially in the beginning of the twentieth century literature in Europe but that were unaccepted in communist Albania for 5 decades.

Some of the key representatives of this generation of poets are: Ervin Hatibi, Luljeta Lleshanaku, Rudian Zekthi, Lindita Arapi, Parid Teferiçi, Gentian Çoçoli, Agron Tufa, Romeo Çollaku etj. It is now almost 20 years that this literature is successfully written but still there's been insufficient room for it in the Albanian literary press and academe.

This article focuses on the poetry of Luljeta Lleshanaku which is presently the most successful Albanian poet abroad and whose poetry is translated into several European languages. There will be applied the text analysis method and the hermeneutical perspective as well as a comparative approach with Yehuda Amichai, the well-known Israeli poet of the second half of the twentieth century.

\title{
2. Searching history, fate and shades; the poetry of Luljeta Lleshanaku
}

Luljeta Lleshanaku is a key representative of contemporary Albanian poetry and is widely considered "a pioneer of Balkan poetry and a rightfully major figure in the current European poetry landscape" (Maintenant, 60th edition).

\begin{abstract}
"Considering the complex context of Albanian literature during the second half of the $20^{\text {th }}$ century one can say that one of the reasons that helped Luljeta Lleshanaku become the most well-known Albanian poet abroad after the 1990s is the fact that her poetry was translated first into English in the USA in 2002 and that she has a long and very successful contact with world literature - both as an academic and as a poet." 1
\end{abstract}

This close contact with the Western world which was absolutely unthinkable for an Albanian poet during communism gave impetus to Luljeta Leshanaku's work and to the representation of contemporary Albanian poetry abroad.

Lleshanaku belongs to the first post-totalitarian generation of Albanian poets. The history of her life during communism is tragic. She belonged to a family that had several members imprisoned or executed on political charges and therefore, her family was persecuted and was a victim of the war of classes. Luljeta Lleshanaku is only one of the poets whose work and life suggests a sociological and historical approach -among other methods- to the study of contemporary Albanian literature. Besides, a comparative and comprehensive approach to world poetry today would be also a possible perspective in order to see the way poets and their work become part of world literature in the present global contexts.

Since Lleshanaku's family was considered an enemy of the state during communism the poet didn't have the right either to university studies or publication of her work. After communism collapsed L. Lleshanaku continued her career as a poet as well as her pursuit of an academic perspective on literature in different countries. She has received many scholarships that had a very positive impact on her literary work such as MacDowell Art Colony, New Hampshire (MarchMay 2013), Literarisches Colloquium Berlin (September 2010); MacDowell Art Colony, New Hampshire (April-May 200); Virginia Centre for Creative Arts (March April 2003), MacDowell Art Colony, New Hampshire (February-April 1999).

Her poetry has received several important prizes such as: Kosova Bookfare 2013 Award, for the best poetic volume of the year; Teodor Keko' Award for Culture Journalism 2011, given for the best TV program on culture; the prestigious Crystal Vilenica Award 2009, the International Prize of Literature in Vilenica Festival, Slovenia - previous winners being Peter Handke, Zbigniew Herbert etc.; The Silver Penn in 2000, which is the National prize for poetry; the Book of the Year Prize awarded from the Eurorilindja Editing House in 1996 and Visions-International 1996, prize for the

\footnotetext{
${ }^{1}$ See Bavjola Shatro, "Between American Contemporary Literature and Albanian Culture: Poetry of Luljeta Lleshanaku and Cathy Song; a Comparative Approach" Edition published by the University of Montenegro, forthcoming in 2014.
} 
translation of poetry awarded by the 'Vision International' magazine, USA.

Papers and reviews on her poetry have appeared in some of the most prestigious journals and magazines of the world such as, World Literature Today, New York Times, The Guardian etc. Her volumes of poetry are translated into English, German, Italian, Polish, Esperanto etc. Since her poetry circulates beyond her culture of origin in translation and therefore has an effective life and is actively present within a literary system beyond that of its original culture (Damrosch 2003) then we have reasons to sustain that Luljeta Lleshanaku is successfully part of world literature and brings an individual voice to the wide scene of world poetry today.

Lleshanaku has published 8 volumes of poetry in Albania and this paper will focus mainly on her most recent volume: Almost yesterday which was published in 2012. This book confirms again what has been rightly noticed by scholars even in her previous volumes of poetry that Lleshanaku can hardly be defined as part of a particular literary tradition even though she is widely considered to be an imagist:

"Luljeta Lleshanaku is a pioneer of Albanian poetry. She speaks with a completely original voice, her imagery and language always unexpected and innovative. Her poetry has little connection to poetic styles past or present in America, Europe, or the rest of the world. And, interestingly enough, it is not connected to anything in Albanian poetry either. We have in Lleshanaku a completely original poet" (Constantine 2011).

Lleshanaku seems to experience what Milosz calls the way "[...] events burdening a whole community are perceived by the poet as touching him in a most personal manner" (Wallace 1993). Therefore she writes a poetry of quiet and deep meditation that deals especially with the small things of everyday life and the immense meaning that they conceal. This meaning is linked especially to the dimension of history in her poetry."

Critics abroad have often and rightfully maintained that despite the dramatic history of her family Lleshanaku tends to avoid focus on the political past of her family and refuses to contract her poetic images and vision about the world by focusing on autobiographical events although they are extremely significant for her life and play a role in her work. Lleshanaku is more driven into an understanding of everyday life experiences and is apt to meditation on the meaning of the small things that take place in our everyday life. Although her poems do not have direct social or political references still history and society are crucial because the poetic images of the poems are often underscored by the lyrical self's meditation on mankind and the dilemmas that define their condition in the world. Personal fates of family members are embodied in the concept of fate and place that the individual has in the world. Hence her poetry has a great variety of topics and successfully avoids simplified reactions towards the past which on the other hand are often found in the poetry of other poets of the same generation.

One of the main characteristics of her poetics is that she creates poetic images that can make concrete even some of the most abstract sides of the reality. Critics have compared her metaphors to those of Shakespeare and Chagall (Dugdale 2011). Her metaphors are created in a very uncommon manner which is completely strange to contemporary poets. She uses concrete elements in the structure of the metaphor in order to refer to completely abstract or other complex realities such as love, death, fear etc. (Dent, 3). On the other hand her similes are quite famous for their complexity and for creating universality in their imagery. Her similes on the other hand are never predictable. They are like a sketch that defines exact coordinates in a territory that remains unknown to us (Herbert 2012).

Almost tomorrow is a poetic volume that seems to highlight these characteristics in another dimension. One could read this volume as chronicle of history and stories that the lyrical self brings together through an imaginative perception of real events. In a way or in another the past is the main poetic concern throughout the volume. The past approaches slowly and almost inevitably through impressions, memories, and emotions which remain in some hidden places of the self. The most secret realities hidden inside the individual often belong to childhood. These realities are related to the taboos of a past time and of events that one cannot talk about and cannot comment with themselves even when alone or in silence. The poems lead one to think that life has a genuine meaning only when we are able to see how those memories of the past silently shape our inner being, our whole future. These mental images are connected among them and brought to the mind of the lyrical self through images of familiar places such as the garden, the home, the village, or uncanny characters from the neighborhood such as a woman believed to be a witch, a prostitute etc. Lleshananku meditates on the determination that seals the fate of man and his place in the world. It is an order that although unspoken, silent and invisible is still there and quietly shows the path where the flow of life will move. The poems: Almost Yesterday, The Man without a Land, Having the Fate Written on Your Face etc. seem to approve this interpretation. The sad and moving story of Lleshanaku's family under communism is only the background of what one sees in the poem

\footnotetext{
2 See Bavjola Shatro, "Between American Contemporary Literature and Albanian Culture: Poetry of Luljeta Lleshanaku and Cathy Song; A Comparative Approach", p.2.
} 
Vertical realities because the essence of the poem is the constant longing for something imperfect, unfinished, unfulfilled, something lost and probably impossible to get back. This is an inevitable deep and silent longing that is somehow reflected in the relationship of the lyrical self with life in the present days. Some details about life in the present shape poetic images of universal perceptions and feelings. This relationship between past, present, visions, pain, hope and memory was well expressed by Ed Ifkovic:

\begin{abstract}
"Although she was raised in the suppressing climate of Socialist realism and extreme censorship, and she is the child of a family that was punished as enemies of the Party and the state Lleshanaku doesn't deal with this past. She enjoys change, new experiences, and this enriches her poetry with amazing visions. Of course this doesn't imply that she ignores the unpleasant world that lies behind her door but she decides to overcome it to live it behind and convert it into universal images of beauty, hope and truth... Through her metaphors she penetrates into the dark worlds of people who are tired but who refuse to give up. Therefore her poems are e proof of the contemporary East European poetry and said in plain words Luljeta Lleshanaku is one of the MASTERS OF POETRY. (Ifkovic 2002)
\end{abstract}

The City of Apples is another poem in the volume Almost Yesterday that deals with a sad and inescapable lack of chance. The individual lacks even the chance to offer to their children a name, to offer to them dreams and promises that would make their childhood have a meaning and encourage them to have hopes for the future. In such circumstances life becomes a reality of forbidden dreams and of continuous and painful challenges. Lleshanaku underlines the fact that behind very common life episodes stand crucial truths about life and about the way we chose to understand it. The greatest mysteries are hidden in the layers of history and history is much more than a set of stories, it is the story which is written within us and where we partake inevitably with our own lives. We write history and read it every day and therefore it is the great set of mysteries that stands right in front of our eyes. The concept of history and several poetic images related to history move silently but relentlessly in all the poems of the volume and deserve further analysis.

History is made by the story of the family and of the individual. When it appears as the sad, long and silent chronicle of the family it becomes the revelation of continuity and determinism in the fate of man. The lack of choice stands like a curse on the head of the individual and even when it seems that they managed to escape this inevitability the past and the generations that lived before touch the present through their descendants lives and through the doubts, fears, and questions about life that we raise continuously. As a result we feel like we've been asking those questions forever and we have continuously longed for answers.

History is also seen specifically from the perspective of the man and the woman and the particular meaning that these two perspectives give to life. Thus history is linked to a condition of search and absence, of loss and unfulfillment, and even guilt that seem to have left their mark in the complex being of a man and a woman. They both long for something specific probably something a little uncanny, which stresses the uncompleted side of one's life story and of history itself.

Memories and impressions from events that seemed little important before are the epicenter of meditation which make the lyrical self re-experience past (hi)story. The dilemma between being and doing is also an important factor that adds to the concept of history as life story where one carries the stories of others before him and will see the self repeated in half in the lives of those who will come after him. Therefore the only thing that remains seems to be memory. The poem Marked represents a perception of history, which is linked to the autobiography of Lleshanaku but also to a larger dimension of the world itself. The world is seen as a fraction of one's own inner reality.

\author{
Marked \\ My deskmate in elementary school \\ had blue nails, blue lips, and a big irreparable hole in his heart. \\ He was marked by death. He was invisible. \\ He used to sit on a stone \\ guarding our coats \\ as we played in the playground, that alchemy of sweat and dust.
}

The one marked to be king

is cold, ready for a free fall

born prematurely from a sad womb.

And the redheaded woman waiting for her drunk husband to return

will go on waiting for one hundred years.

It isn't the alcohol; she is marked by 'waiting.' 
And he only as guilty as an onlooker pushed indoors by rain.

What's more, it isn't the war

that took the life of the young boy

with melancholy eyes. He was marked as well, born to be on the recruiter's list.

Melancholy is the standard arsenal of war.

And then there is one marked for survival who will continue to eat his offspring like a polar bear that never notices the warming climate.

All of them are as closed as theorems, their sky a rental home

where hammering even a single nail of change is forbidden.

They are waiting for their next command, which they will ignore anyway

like the Argonauts who filled their ears with wax

and rowed on through the sirens' path.

(translated by Henry Israeli \& Shpresa Qatipi)

It is easy to find in this poem the strong echo of a nervous "Why???" and also a clear although painful acknowledgment of the unchangeable. History is all there is to talk to and to talk about because it is already written and you are already part of it. All in the world is like a theorem and exists inside a theorem.

While the will to survive becomes part of the perception of history the sacred and the profane merge. This new reality that is formed seems to shed light on the greatest mysteries of life which are not the invisible things but the visible and concrete ones. Although sometimes Lleshanaku's poems lack stylistic figures in many verses the texture of her poems is very dense with meaning and allusions. Doubt, impossibility, fear, shame, anxiety, complex and unclear desires become concrete in a very spontaneous way and through a direct introduction, which is probably one of the greatest characteristics of Lleshanaku's poems. The first verse of the poems is usually the key to interpretation because it is a bold statement that will be elaborated further in the poem as a mathematical theorem which needs analysis after it's been stated. And when talking about memory the logic of theorems is more evident. Theorems stress the concept of the unchangeable.

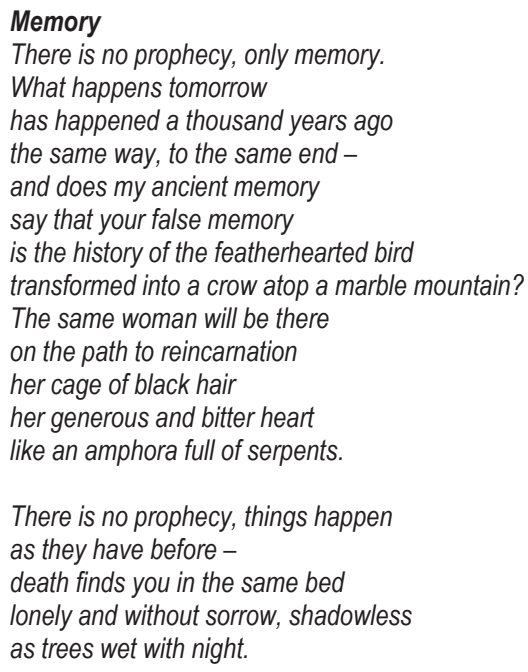

There is no prophecy, things happen as they have before death finds you in the same bed lonely and without sorrow, shadowless as trees wet with night.

There is no destiny, only laws of biology; 


\title{
fish splash in water
}

pine trees breathe on mountains.

(translated by Henry Israeli \& Albana Lleshanaku)

The poetic images in Lleshanaku's poems are usually direct and in some aspects they are very similar to the images in the poems of Yehuda Amichai. These images make history very concrete. History is almost as present and concrete as everyday events and still it is also universal, abstract and incomprehensible.

Lleshanaku's poetry has been often credited to "... maintain much of the elegance of the great post-WWII European tradition; it evokes the likes of Herbert, Amichai, Pagis, Cassian." (Fowles 2011). It is probably the quiet and clear voice of memory and history and the sense of responsibility towards the others lives and history that defines the affinity of her poetry with that of the other eminent world poets and with Yehuda Amichai in particular. In one of her interviews Luljeta Lleshanaku has confirmed that it would not to be an accident if there would be any similarity between her poetry and that of Amichai because he is her favorite poet and they both belong to countries which have suffered greatly. As Lleshanku herself maintains the similarity with Amichai could stand on the fact that he deals with the real world and real history and with a collective ego which dominates the individual ego (Fowles 2011). These are elements of Lleshanaku's poetry that we tried to synthesize in this article so far.

\section{Yehuada Ahmichai: Life (hi)story in poetry}

It is widely accepted that Yehuda Amichai who is well-known for his impressive and unique style is Israeli's most famous and translated poet since we find his verses translated into 37 languages. His poetry seems to be influenced by the poetry of Dylan Thomas, W.H.Auden and Rilke. History, war, life, love and death are among the most important topics in Amichai's poetry but the range of topics as well as poetic images that embody them in his poetry is wide and complex. Thematic approaches on the poetry of Amichai have been widely considered by scholars (see Abramson 1989) while his poetic language with the extensive use of striking similes and his affinity to metaphysics has also been an object of interest to scholars that draw lines of comparison and similarities between Amichai and other poets of previous literary streams such as the metaphysical English poets (see Fishelov 1992). This seems to prove the universality of his poetry and the unique communication that it has developed with world literature and its history. Poetry and language were Amichai's greatest allies in his poetic journey of discoveries and reconfirmation of the old and enigmatic truths of mankind. He couldn't find better allies than poetry and language probably because "the only cultural construct Amichai had complete confidence in was "the human capacity for language." (Bloch \&Kronfeld 2000). History and memory and the necessity to remember are the defining dimension of his poetry and the test that language has to undergo in order to become poetry. And in poetry the sacred and the profane are no longer either divided or incompatible.

"If even a toothbrush, in Amichai's universe, can be a sacred object, how much more sacred then must be the hand that holds the toothbrush, and the lovers' hands caressing each other, and the disembodied memories themselves, and the minds remembering. With Amichai, ripples of implication set out from the simplest phrases and spread indefinitely. His lines are almost prosaic in their conversational quality, and yet they are subtly rhythmic, lyric, layered with associations. (Kessler 2000)

If we focus on the poem This is the Story of Dust we notice that the lyrical self perceives himself to be half his father and half his son (Abramson 1989). His condition is that of being in between, in the middle and embodies the dramatic sense of being himself a half, never fully complete and never fully perishing. Memory, time and history have a very complex meaning in this context and the relationship between time, memory and the inevitable condition of being alone in a universal personal loneliness - while you carry the memories of generations with you- is more than evident:

\author{
This is the story of dust \\ This is the story of dust: between my going out in the morning \\ and my return in the evening half of what is to happen happens \\ and in my sleep, the other half. Everything without me. \\ In my pocket lie the keys of houses long gone, \\ in my bag stamps \\ for letters I no longer have to send.
}

This is the story of dust that forgot the rocks from which it came. 


\author{
Sadness and joy that were a liquid measure \\ are now a dry measure. \\ The fruit of the tree makes way for new fruit \\ without a Last Will of sadness: even a joyful harvest \\ will end quietly, not only a tear.
}

\author{
I'm already at such a distance \\ that I don't remember if what I did \\ I did to my father \\ or if my son did it to me.
}

Amichai's poetry is autobiographical more in appearance and in mood rather than in substance (Abramson, 1989). Abramson maintains that even by analyzing the way childhood is presented in Amichai's poetry one notices that although much of his writing is founded on nostalgia about childhood still the depiction of childhood plays little part in his poetry. "There's demarcation of the geographical and psychological areas of childhood but there is not explicit rendering of childhood experience." (Abramson 1989). In Amichai's poetry one notices that life events are not the destination of the lyrical meditation but:

\footnotetext{
"...become the symbolic landmarks that explain or serve to emphasize what the poet has deemed problematical areas in the life of his literary self. He has therefore written autobiographically but a poetic myth of himself, a journey on progress of the self during which certain obstacles are encountered and challenged with varying degrees of success or failure." (Ibid.)
}

History is viewed through the lyrical self's world. In this world the past and the present are no longer divided and chronology loses meaning. Therefore the lyrical self stands between a metaphysical time and the numerous generations, between the living and the dead which form not only the story of the family but the history of man in the world while perceiving deep loneliness and loss of the great spiritual as well as psychological legacy that was gathered within him in time. Therefore, it's been rightly stated that time in Amichai's poetry is more a metaphysical time rather than a chronological time (Abramson 1989). The way events are experienced and perceived by the lyrical self define the role of these events in the long process of remembrance that takes place in his poetry. Memory is the dimension where reality and an imaginative, psychological configuration of the reality inevitably meet and it is only through poetic images that they are formulated. Eventually they give us a unique perception of history and life story.

\title{
4. Comparing (hi)stories: Luljeta Lleshanaku and Yehuda Amichai
}

Similarities between the poetry of Luljeta Lleshanaku and Yehuda Amichai become evident even after this short and synthesizing view of some of the main characteristics of their work. The poetic images of history are among the elements where similarities are mostly seen.

It is a fact that in Lleshanku's poems even when she refers to members of her family and to any aspects of her own life she still doesn't talk directly about herself and about the fate of a simple individual. Life story becomes an insight on the concept of history as a reality where the individual acknowledges the juncture point between his fate and that of the society and mankind. In such case life events from childhood, from one's family life and its tragedies are projected as realities of all time and beyond chronology. The similarity with Amichai's poetry in this aspect is clear because the history of mankind and of the place of man in the world is seen through the story of one's life but surely not limited to one geographical or temporal reality.

Lleshanku's poetry resembles that of Amichai also because both poets seem to ask silently but persistently why something happens and this question is openly and steadily directed to history. It doesn't become an abstract question and eventually the literary text doesn't become solipsistic either. Instead the poem becomes a clear voice of recall, of remembrance and insight that sees the fate of the individual linked to that of the society as whole. The need of an answer, of an explanation that can provide some logic, a cause or some sense to all the pain and suffering that the individual goes through as well as to the beauty that emanates from simple things are constantly present. The only possible answer to these pending questions is the poetic images and allusions, the metaphoric solutions that analyze the mysterious nature of mankind and history. Meditation on history is done quietly, without rush, without anger, without impatience although in the case of Lleshanaku we detect some nervous questioning sometimes while she sees things crumbling in front of her when she re-lives history in her everyday life.

Both poets seem to share a reverence for language, for the written word and for the inner world within language 
where words can no longer provide a way to express ourselves. It is here that starts the stuttering because something in the coexistence and interaction between language and thought simply stops. In this moment metaphor is the only solution that the puzzles and enigmas of modern history can ever have.

In both poets work history and biography are met and intertwined in order to offer the larger universal view of the history of the collective where one necessarily belongs. Finding oneself and your history right in the middle of a global and enormous universal reality makes one believe that there is no escape from this flow but there is a place though where only you can be and only you can apprehend. While moving toward the future we meet history and our own story all over again. This is part of the poetic enigma that seems to explain much of the concept of history in the poetry of both these authors.

In one of his poems Amichai says that he is always Cain because he goes around something that he won't do or around something that he cannot undo (Amichai 1997). This reminds us of Lleshanku's journey around the unchangeable route of life and around some realities that are pending inside the lyrical self and are still far from reach.

\section{Conclusions}

Rather than a thorough analysis of their poetry this article is mostly an introduction to a comparative approach on the poetry of Luljeta Lleshanaku and Yehuda Amichai. It is an introduction to a possible and different perspective of reading their poetry in the context of world literature. Paradoxically the work of Lleshanaku herself is still not thoroughly analyzed in her country although especially academics and critics abroad have been clear on their appraisal for her poetry. On the other hand the poetry of Amichai -the unquestionable representative of contemporary Israeli poetry- was firstly introduced in Albania about 17-18 years ago when selected poems by Amichai were translated by a well-known Albanian poet Bardhyl Londo and were published in Tirana (Amichai 1997). This article aimed to identify some of the similarities between the poetry of Lleshanaku and Amichai especially regarding the perception of history and the place of the individual in history.

Lleshanaku maintains that influences from Amichai's poetry in her own work are quite possible because he is her favorite poet and she is most familiar with his poetry. Analysis of Lleshanaku's last volume of poetry Almost yesterday and Amichai's poetry proves the similarities at the level of topicality and even poetic images. They share some common perception in the way they create and use metaphors and similes as well as the way they make concrete the abstract and extremely complex realities of the inner life of the individual and his story.

Luljeta Lleshanaku and Yehuda Amichai seem to suggest us to approach poetry through both text analysis and a historical and cultural approach. This approach allows a better understanding of the way one literary phenomenon i.e. the metaphorical answer -which is also the only possible one- to the great mysteries and dilemmas of the world can draw near two poets belonging to two different cultures. Thorough analysis of their poetry can contribute to a better understanding of world literature and of literature in the world.

\section{References}

Abramson, Glenda. (1989). "The Writing of Yehuda Amichai: A Thematic Approach". New York: SUNNY Press.

Amichai Yehuda. (1997). "Misteri i përjetshëm". Tiranë: Dituria.

Bloch, Chana and Chana Kronfeld. (2000) "Amichai's Counter-Theology: Opening Open Closed Open," in Judaism 49.2, 153-68.

Constantin, Peter. (2011). Introduction to Haywire, New and Selected Poems, by Luljeta Lleshanaku Highgreen Tarset: Bloodaxe Books. David Damrosch. (2003). "What is World Literature". Princeton University Press.

Dent, Alan. "Haywire by Luljeta Lleshanaku". Mistress Quickly's Bed, Issue 3.

Elsie, Robert. (2001). "Historia e letërsisë shqipe". Pejë: Dukagjini.

Fishelov, David. (1992). "Yehuda Amichai: A Modern Metaphysical Poet" in Orbis Litterarum Volume 47, Issue 2, pages 178-191.

Fowler, S.J. (2011) "Interview", Maintenance \#6. [Online] available: http://www.3ammagazine.com/3am/maintenant-60-luljeta-lleshanaku/ (May 9, 2011)

Herbert, M.N. (2012). Poetry Review, London, quoted in Luljeta Lleshanaku. (2012) "Pothuajse dje". Tiranë: Ombra GVG.

Ifkovic, Ed. (2002). Preface in "Multicultural review".

Kessler, Stephen. (2000). "Theology for Atheists; Yehuda Amichai's poetry of paradox". Express Books. ('The New York Times', 23 September 2000.)

Shatro, Bavjola. (2014). "Between American Contemporary Literature and Albanian Culture: Poetry of Luljeta Lleshanaku and Cathy Song". University of Montenegro (forthcoming).

Vinca, Agim. "Me poetin dhe kritikun Agim Vinca". (2007). [Online] available: http://www.toena.com.al/toena Irevista_Universi_Shqiptar_i_Librit/intervista/Me_poetin_dhe_kritikun_Agim_Vinca.html

Wallace, Patricia. (1993). "Divided Loyalties: Literal and Literary in the Poetry of Lorna Dee Cervantes, Cathy Song and Rita Dove", MELUS, Vol. 18, №. 3, 3-19. 